\title{
Penerapan Model Pembelajaran Project Citizen untuk Meningkatkan Critical Thinking Mahasiswa
}

\author{
Herinto Sidik Iriansyah \\ STKIP Kusuma Negara \\ herinto_sidik@stkipkusumanegara.ac.id
}

\section{Sejarah Artikel}

diterima 28/03/2020 disetujui 6/06/2020

\begin{abstract}
This study aims to improve students' critical thinking through the application of the Project Citizen Learning model to second semester students of Class A S1 Elementary School Teacher Education courses in the National Character Education Course. This research is a collaborative classroom action research. The study was conducted at STKIP Kusuma Negara 2018/2019 academic year with 30 research subjects. The data collection technique uses observation. The results showed that the application of the Project Citizen Learning model with stages (1) Identifying problems, (2) Selecting problems as class study material, (3) Gathering information, (4) developing class portfolios, (5) Presenting portfolios, and (6)) Reflecting the learning experience, can improve students' critical thinking. This is evidenced by the maximum cycle of 14 students in the first cycle has a high critical thingking and in the second cycle, a maximum of 27 students have a high critical thingking.

Keywords: critical thingking, Project Citizen Learning Model, and Students PGSD
\end{abstract}

\begin{abstract}
Abstrak
Penelitian ini bertujuan untuk meningkatkan critical thingking mahasiswa melalui penerapan model Pembelajaran Project Citizen pada mahasiswa semester II Kelas A program studi S1 Pendidikan Guru Sekolah Dasar pada Matakuliah Pendidikan Karakter Bangsa. Penelitian ini adalah penelitian tindakan kelas secara kolaboratif. Penelitian dilaksanakan di STKIP Kusuma Negara Tahun akademik 2018/2019 dengan subjek penelitian sebanyak 30 mahasiswa. Adapun teknik pengumpulan data menggunakan observasi. Hasil penelitian menunjukkan bahwa penerapan model Pembelajaran Project Citizen dengan tahapan (1) Mengidentifikasi masalah, (2) Memilih masalah sebagai bahan kajian kelas, (3) Mengumpulkan informasi, (4) mengembangkan portofolio kelas, (5) Menyajikan portofolio., dan (6) Merefleksikan pengalaman belajar, dapat meningkatkan critical thingking Mahasiswa. Hal tersebut dibuktikan dengan Pada siklus I maksimal 14 mahasiswa memiliki critical thingking yang tinggi dan pada siklus II, sebanyak maksimal 27 mahasiswa mempunyai critical thingking yang tinggi.

Kata kunci: critical thingking, model pembelajaran Project Citizen, dan mahasiswa PGSD
\end{abstract}




\section{PENDAHULUAN}

Pendidikan yang dltanamkan pada Perguruan Tinggi diharapkan mampu memberikan potensi mahasiswa guna menghadapi perkembangan di era revolusi industri 4.0 Menuju era Society 5.0. yang menonjol pada 4.0 adalah artificiall intellegent $(\mathrm{Al})$. Al dapat juga disebut dengan perkembangan teknologi komputer yang mengadopsi keahlian manusia. Society 5.0 merupakan sebuah komunitas masyarakat terpusat pada manusia. Manusia yang dimaksud adalah yang menyeimbangkan kemajuan ekonomi melalui penyelesaian permasalahan social, dengan melalui sistem kehidupan yang mengintegrasikan dunia maya dan dunia nyata, hal ini disampaikan menurut Kantor Kabinet Jepang COJG (2019). Pada Society 5.0, modal bukan lagi yang utama dalam memulai usaha, namun suatu data yang menghubungkan dan menggerakkan segala kebutuhannya, Dapat pula terlihat layanan medis dan pendidikan atau sekolah, dari tingkat pendidikan anak usia dini hingga perguruan tinggi. Dengan demikian generasi penerus bangsa (mahasiswa) harus mampu menghadapi berbagai era ke depan.

Reeve (2016) also pointed out the importance of 21st century and critical thinking skills needed. Salah satunya adalah Penanaman Critical thingking kepada mahasiswa. Hal ini merupakan salah satu cara untuk membekalinya dalam mengahadapi perkembangan zaman. Perkembangan zaman semakin melesat cepat. Perkembangan zaman akan terjadi disetiap hembusan nafas manusia. Perubahan merupakan suatu proses yang lazim di bumi tercinta khususnya di Indonesia.
Perubahan tersebut seakan-akan selalu menerkam bagi manusia yang tidak mampu untuk berbuat menyikapi perubahan. Manusia yang menolak perubahan akan tergilas, hal ini karena perubahan merupakan suatu keniscayaan. Banyak pakar menyampaikan bahwa perubahan merupakan dimensi waktu. Perubahan memiliki jejak atau membekas dalam setiap sendi kehidupan manusia. Dengan demikian dari era perubahan zaman yang terjadi, penanaman critical thingking dianggap perlu dikalangan kaum intelektual (mahasiswa). Adapun Tujuan dari berpikir kritis adalah untuk mencapai pemahaman yang mendalam (Johnson, 2002:65). Melalui kemampuan berpikir kritis, para mahasiswa mampu untuk menelaah dan bertindak menyikapi perubahan zaman yang ada.

Definisi berpikir kritis dijelaskan Menurut Ennis, bahwa yang mendefinisikan berpikir kritis sebagai pemikiran wajar, reflektif yang difokuskan pada memutuskan apa yang harus percaya atau lakukan (Norris dan Ennis, 1989 pada Fisher 1997). Pendapat lain menurut Costa and Kallick (2014) critical thinking is a mental process. Dengan demikian berpikir kritis merupakan proses mental dan memutuskan yang melibatkan proses pembuatan keputusan yang disertai dengan tujuan.

Salah satu potensi yang harus dikembangkan, dibentuk, dan ditingkatkan di perguruan tinggi adalah berpikir kritis para mahasiswanya. Hal ini erat kaitannya dengan kebutuhkan dalam berprestasi di dunia kerja. Salah satu cara dalam meningkatkan kemampuan berpikir 
kritis mahasiswa perlu dilakukan inovasi pembelajaran, Suparni (2016). Inovasi pembelajaran dapat ditanamkan melalui seluruh matakuliah yang disampaikan oleh dosen. Dengan pembelajaran yang inovatof, dapat membawa mahasiswa menjadi pemikir yang kritis.

Pendidikan karakter bangsa (PKB) merupakan matakuliah dengan beban 2 sks pada STKIP Kusuma Negara. Pada mata kuliah ini mahasiswa mampu belajar untuk mengkaji tentang hubungan manusia dengan sesamanya dan juga negara kesatuan Republik Indonesia. Meliputi nilai-nilai rasa hormat, kejujuran, disiplin dan tanggung jawab, serta patriotisme. Melalui mata kuliah Pendidikan Karakter, para mahasiswa diharapkan memiliki kebiasaan dan budaya untuk melaksanakan nilai-nilai tersebut dalam kehidupan sehari-hari. Kegiatan kuliah meliputi perkuliahan, observasi, refleksi, dan diskusi kelas. Menurut Chrisnaji Banindra Yudha (2019) Dalam proses pembelajaran, tidak hanya menekankan pada kecerdasan, inovasi, kritis dan kreatif, akan tetapi penekankan pada penanaman nilai karater yang luhur juga diperlukan. Dalam mempelajari matakuliah PKB seharusnya para mahasiswa banyak membaca referensi baik dari jurnal penelitian, mengikuti seminar, buku sumber, observasi ke lapangan atau sekolah, berita yang aktual yang sedang bergulir baik segi politik, sosial, karakter, kebangsaan dan yang menyangkut patriotisme. Oleh karena itu, hal tersebut menjadi referensi utama dalam belajar PKB, dengan demikian mahasiswa mampu berpikir kritis mengenai kajian karakter bangsa dan pemberitaan yang sedang bergulir.

Para mahasiswa PGSD semester II Kelas A, memiliki Critical thinking yang belum maksimal. Hal ini Saat proses pembelajaran yang berlangsung di dalam kelas, para mahasiswa belum mampu mengungkapkan kekritisan mengenai beberapa materi yang dibahas. Pada saat observasi kompetensi dasarnya adalah Menganalisis proses pembentukan karakter dalam diri manusia dan kegiatan pembelajaran Mengondisikan lingkungan yang mendukung pembentukan karakter. Pada saat pembelajaran mahasiswa diminta untuk menyampaikan pendapat mengenai materi dalam 5 menit. Hanya ada 5 mahasiswa yang mampu memahami permasalahan yang diberikan, mampu memberikan fakta atau bukti yang relevan, menggunakan informasi dari berbagai sumber seperti jurnal maupun referensi buku elektronik atau yang lainnya, mampu menyampaikan contoh kasus yang sedang bergulir.

Menurut Ennis (Chrisnaji Banindra Yudha 2019) Bahwa kriteria orang berpikir kritis disingkat FRISCO (Focus, Reason, Inference, Situation, Clarity, Overview), adapun secara lengkap disajikan dalam tabel berikut

Tabel 1. Kriteria Berpikri Kritis

\begin{tabular}{|l|l|}
\hline Kriteria Berpikir Kritis & \multicolumn{1}{|c|}{ Indikator } \\
\hline Focus & $\begin{array}{l}\text { 1) Siswa memahami permasalahan pada soal } \\
\text { yang diberikan. }\end{array}$ \\
\hline Reason & $\begin{array}{l}\text { Siswa memberikan alasan berdasarkan } \\
\text { fakta/bukti yang relevan pada setiap langkah }\end{array}$ \\
\hline
\end{tabular}




\begin{tabular}{|l|l|}
\hline & dalam membuat keputusan maupun kesimpulan. \\
\hline Inference & $\begin{array}{l}\text { 1) Siswa membuat kesimpulan dengan tepat. } \\
\text { 2) Siswa memilih reason (R) yang tepat untuk } \\
\text { mendukung kesimpulan yang dibuat. }\end{array}$ \\
\hline Situation & $\begin{array}{l}\text { Siswa menggunakan semua informasi yang } \\
\text { sesuai dengan permasalahan. }\end{array}$ \\
\hline Clarity, & $\begin{array}{l}\text { 1) Siswa menggunakan penjelasan yang lebih } \\
\text { lanjut tentang apa yang dimaksudkan dalam } \\
\text { kesimpulan yang dibuat. } \\
\text { 2) Jika terdapat istilah dalam soal, siswa dapat } \\
\text { menjelaskan hal tersebut. } \\
\text { 3) Siswa memberikan contoh kasus yang mirip } \\
\text { dengan soal tersebut. }\end{array}$ \\
\hline Overview & $\begin{array}{l}\text { 1) Siswa meneliti atau mengecek kembali secara } \\
\text { menyeluruh mulai dari awal sampai akhir (yang } \\
\text { dihasilkan FRISC) }\end{array}$ \\
\hline
\end{tabular}

Adapun kriteria berpikir kritis ini, digunakan peneliti sebagai indicator. Dengan demikian, sesuai kriteria diatas maka para mahasiswa PGSD STKIP Kusuma Negara semester II kelas A memiliki critical thinking yang belum maksimal. Maka perlu diberikan alternative model pembelajaran yang kontektual yang mampu mengembangkan daya pikir dan pengetahuannya.

Model pembelajaran yang mampu mengembangka daya pikir dan pengetahuan adalah Model Pembelajaran Project Citizen. Menurut Budimansyah (2009) bahwa Project Citizen adalah pembelajaran yang berbasis masalah untuk mengembangkan pengetahuan, kecakapan, dan watak warga negara demokratis yang memungkinkan dan mendorong keikutsertaan dalam pemerintahan dan masyarakat sipil hal ini berorientasi pada proses berpikir kritis, kreatif, dan juga pemecahan masalah. Adapun langkah pembelajaran Model Pembelajaran. Project Citizen menurut Rohani dan Muhammad (2019) adalah
Mengidentifikasi masalah, (2) Memilih masalah sebagai bahan kajian kelas, (3) Mengumpulkan informasi, mengembangkan portofolio kelas, (5) Menyajikan portofolio, dan (5) Merefleksikan pengalaman belajar. Langkah pembelajaran tersebut digunakan dalam penelitian ini.

Beberapa penelitian tentang penerapan model pembelajaran project citizen, diketahui efektif. Penelitian yang dilaksanakan oleh Rohani dan Muhammad (2019), bahwa Penerapan model project citizen dapat meningkatkan keterampilan intektual hal ini dapat dilihat dari hasil analisis data keterampilan intektual pada siklus I mencapai $68 \%$, siklus II mencapai 74 $\%$ dan siklus III mencapai $85 \%$.

Luqman (2017) dari hasil penelitiannya menyampaikan bahwa bahwa penerapan model pembelajaran project citizen dapat meningkatkan keterampilan berpikir kritis dan kreatif, yang dilakukan melalui enam langkah, yaitu: mengidentifikasi masalah; memilih masalah; mengumpulkan informasi; 
mengembangkan

portofolio; menyajikan portofolio; dan refleksi pada pengalaman belajar. Penerapan model pembelajaran project citizen dapat meningkatkan keterampilan berpikir kritis, yaitu Siklus I sebesar 74,3 menjadi 83,9 pada Siklus II. Selain itu, penerapan model pembelajaran project citizen juga dapat meningkatkan keterampilan berpikir kreatif, yaitu Siklus I sebesar 70,8 menjadi 75,6 pada Siklus II.
Rumusan masalah penelitian ini adalah (1) bagaimana Pelaksanaan Model Pembelajaran Project Citizen Untuk Meningkatkan Critical Thinking Mahasiswa? (2) bagaimana Penerapan Model Pembelajaran Project Citizen Untuk Meningkatkan Critical Thinking Mahasiswa. Selain itu Tujuan dari penelitian ini untuk mengetahui peningkatan kemampuan Critical Thinking mahasiswa melalui model pembelajaran project citizen.

\section{METODE}

Jenis Penelitian dalam peneliti melaksanakan tindakan dan penelitian ini adalah penelitian pada tahap analisis dan refleksi. Oleh tindakan kelas (classroom action karena itu, Penelitian tindakan kelas research). Menurut Suharsimi Arikunto dilaksanakan untuk meningkatkan (2010: 130), bahwa penelitian proses pembelajaran. Dalam tindakan kelas yaitu suatu pelaksanaannya dibantu oleh pencermatan terhadap kegiatan yang kolaborator guna mencapai hasil sengaja dimunculkan, dan terjadi dalam sebuah kelas. Menurut Kemmis dan Mc Taggart (Parjono, dkk. 2007: $10)$, "the approach is only action research when it is collaborative, through the critically examined action of individual group members", yang maknanya adalah dalam penelitian tindakan kelas diperlukan kolaborator, adalah orang yang mampu secara kritis memberi masukan pada saat yang diharapkan.

Dalam penelitian ini langkahlangkah penelitian mengacu pada model Kemmis dan Mc Taggart (1988: $11)$, terdapat 4 tahapan yang lazim dilalui, yaitu (1) perencanaan, pelaksanaan (tindakan), pengamatan (observasi) dan refleksi. Adapun model masingmasing tahap dapat dilihat pada halaman berikutnya

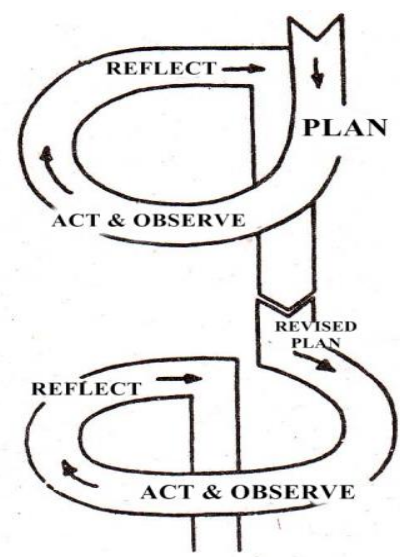

Gambar 1. Tahapan pada siklus Penelitian Tindakan Kelas Kemmis \& Mc Taggart (1988: 11) 
Subjek Penelitian ini adalah semua mahasiswa Prodi S1 Pendidikan Guru Sekolah Dasar (PGSD) semester II kelas A Sebanyak 30 Mahasiswa. Adapun tempat pelaksanaannya di STKIP Kusuma Negara Jakarta.

Teknik pengumpulan data yang digunakan dalam penelitian ini adalah dengan menggunakan non tes. Teknik menggunakan

lembar pengamatan atau lembar observasi yang telah dipersiapkan sebelumnya. Observasi dalam penelitian ini dengan cara melakukan pengamatan langsung dan pencatatan mengenai pelaksanaan pembelajaran di kelas. Pelaksanaan pembelajaran di kelas menggunakan model pembelajaran Project Citizen oleh dosen. Observasi dilakukan dengan menggunakan digunakan untuk mengukur critical thingking adalah melalui observasi, hal ini digunakan ntuk mengukur ranah afektif. Observasi Menurut Parjono, dkk (2007: 43), Teknik observasi merupakan teknik monitoring dengan melakukan observasi/pengamatan terhadap sasaran pengukuran, dengan lembar observasi yang telah disusun sebelumnya. Adapun hal-hal yang diobservasi dalam peneliti ini yaitu sesuai indicator critical thingking yaitu Focus, Reason, Inference, Situation, Clarity,Overview. Adapun Teknik Analisis data dalam penelitian ini meliputi reduksi data, penyajian data, dan penarikan kesimpulan.

\section{PEMBAHASAN}

Pembelajaran dengan model Project Citizen menciptakan pembaharuan pada Prodi S1 PGSD STKIP Kusuma Negara.

\section{Peningkatan Critical Thingking Mahasiswa}

Melalui pembelajaran ini dapat meningkatkan critical thingking mahasiswa PGSD STKIP Kusuma Negara. Adapun hasil peningkatan Critical Thingking Dapat terlihat pada tabel 1 berikut ini:

Tabel. 2

Peningkatan Critical Thingking Mahasiswa Siklus I dan siklus II

\begin{tabular}{ccc}
\hline Pertemuan & \multicolumn{3}{c}{ Critical Thingking } \\
\cline { 2 - 3 } & Siklus I & Siklus II \\
\hline I & 6 siswa & 19 siswa \\
\hline II & 9 siswa & 23 siswa \\
\hline III & 14 siswa & 27 siswa \\
\hline
\end{tabular}

Adapun Grafik peningkatan pembelajaran disajikan pada grafik critical thingking mahasiswa dalam berikut 


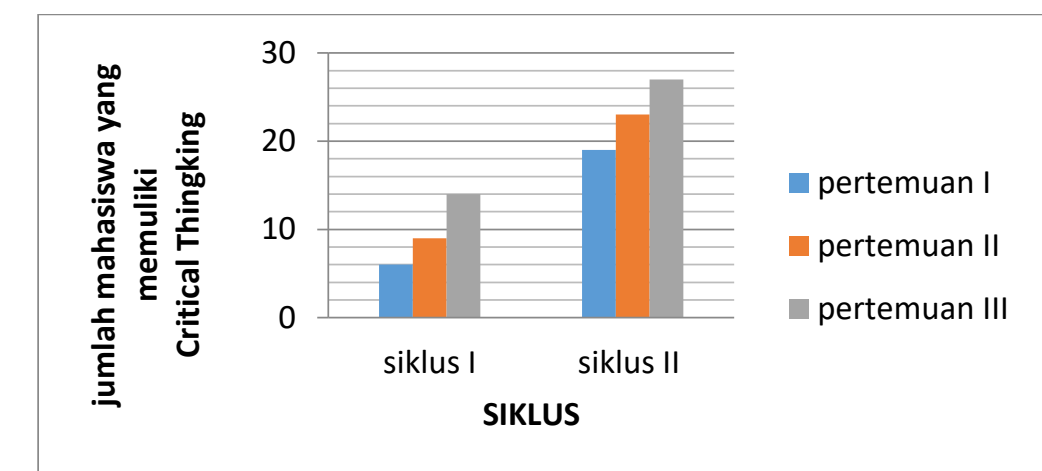

Gambar 2. Peningkatan Critical Thingking Mahasiswa

Secara umum, hasil analisis critical thingking mahasiswa siklus I, pertemuan 1 sebanyak 6 mahasiswa dari 30 mahasiswa yang mempunyai critical thingking, pertemuan II sebanyak 9 mahasiswa dari 30 mahasiswa yang mempunyai critical thingking, pertemuan III sebanyak 14 mahasiswa dari 30 mahasiswa yang mempunyai critical thingking. Hasil ini menunjukkan bahwa critical thingking mahasiswa mengalami peningkatan di setiap pertemuan pada siklus 1 .

Secara umum, hasil analisis critical thingking mahasiswa siklus II mengalami peningkatan. Hasil analisis critical thingking mahasiswa siklus II, pertemuan 1 sebanyak 19 mahasiswa dari 30 mahasiswa yang mempunyai critical thingking, pertemuan II sebanyak 23 mahasiswa dari 30 mahasiswa yang mempunyai critical thingking, pertemuan III sebanyak 27 mahasiswa dari 30 siswa yang mempunyai critical thingking. Hasil ini menunjukkan bahwa critical thingking mahasiswa mengalami peningkatan di setiap pertemuan pada siklus II. Hasil ini menunjukkan bahwa critical thingking mahasiswa mengalami peningkatan di setiap siklus. Variabel critical thingking telah mencapai kriteria keberhasilan yang ditetapkan. Kriteria keberhasilan apabila 24 mahasiswa atau sebesar $80 \%$ dari 30 mahasiswa memiliki critical thingking, hal ini dilihat dari hasil observasi.
Hal Ini sesuai dengan penelitian yang dilaksanakan oleh Luqman (2017), bahwa proses pembelajaran yang menerapkan model pembelajaran Project Citizen terdapat peningkatan kualitas proses langkah-langkah model pembelajaran Project Citizen sehingga dapat meningkatkan keterampilan berpikir kritis dan kreatif.

Selain itu berdasarkan penelitian yang dilaksanakan oleh Dina Indriani (2019) bahwa mahasiswa mampu memposisikan diri pada permasalahan yang ada, mampu menguraikan permasalahan yang ada, mampu mencari dan menemukan solusi tentang permasalahan yang ada, selain itu mahasiswa mampu memberikan penjelasan yang sederhana, mampu membangun keterampilan dasar, mampu membuat referensi, mampu membuat penjelasan lebih lanjut, dan mampu mengatur strategi dan taktik. Melalui beberapa indicator tersebut membuktikan bahwa mahasiswa program studi PPKn dan Pendidikan Matematika Univ Muhammadiyah Ponorogo mampu memiliki kemampuan berpikir kritis pada matakuliah Pendidikan Kewarganegaraan melalui project citizen. 


\section{Penerapan Critical Thingking Mahasiswa}

Critical thingking mahasiswa mengalami peningkatan tiap pertemuan. Peningkatan ini dikarenakan oleh mahasiswa merasa senang dan aktif dalam proses pembelajaran menggunakan project citizen yang sedang berlangsung. Adapun Penerapan model project citizen pada mata kuliah Pendidikan Karakter Bangsa diuraikan dalam penjelasan berikut ini: tahap 1) Mengidentifikasi masalah, pada tahap ini dosen pengampu matakuliah memberikan materi dengan kompetensi dasarnya adalah Menganalisis proses pembentukan karakter dalam diri manusia dan kegiatan pembelajaran Mengondisikan lingkungan yang mendukung pembentukan karakter untuk didiskusikan. Setelah itu dosen memberikan penjelasan tentang proses pembentukan karakter yang disertai contoh dalam kehidupan sehari-hari yang saat ini sedang bergulir di masyarakat.

Tahap 2). Memilih masalah sebagai bahan kajian kelas. Dosen mengarahkan mahasiswa untuk membentuk kelompok. Dikarenakan ada 30 mahasiswa, maka dibentuk 5 kelompok. Tiap kelompok memilih satu masalah dan hal ini merupakan pilihan secara mufakat oleh seluruh mahasiswa di kelas tersebut, agar digunakan sebagai bahan kajian kelas. Mahasiswa pada masingmasing kelompok untuk mengkaji dan menyelesaikan masalah. Dalam proses ini mahasiswa mampu mengembangkan focus (indikator pertama critical thingking).

Tahapan ke 3) Mengumpulkan informasi. Setelah kelompok mampu menentukan permasalahan yang akan dibahas, maka tiap kelompok mahasiswa menentukan sumber atau bahan sebagai referensi yang akan diambil sebagai bahan kajian atau referensi tambahan. Dosen memberikan informasi, dapat memperoleh referensi tambahan melalui jurnal ilmiah yang sudah dipublikasikan, media elektronik dengan domain yang utama/sumber utama, dapat juga dengan pencarian di google. Pada tahap ini mahasiswa terbiasa menggunakan Reason (indicator kedua critical thingking) atau mahasiswa memberikan alasan berdasarkan fakta/bukti yang relevan pada setiap langkah dalam membuat keputusan maupun kesimpulan selain itu didukung dengan data dan informasi yang akurat dari sumber yang terpercaya.

\section{Tahapan}

ke mengembangkan portofolio kelas, Mahasiswa mampu mengembangkan portofolio dari tahapan sebelumnya. Pada tahapan ini ide-ide cemerlng mahasiswa diasah untuk berpikir kritis, kreatif dan mampu mengembangkan permasalahan serta memberikan tanggapan mengenai permasalahan yang sedang dikaji. Hal ini sesuai dengan penelitian yang dilaksanakan oleh Nada dan Solihin (2017) bahwa selama aktivitas pembelajaran yang mendukung keterampilan berpikir kritis siswa, banyak siswa yang mampu melakukan setiap tahapan dengan baik dan semakin aktif selama pembelajaran. Pada tahapan ini Situation (indicator keempat critical thingking) mampu terolah dengan sendirinya serta mahasiswa menggunakan semua informasi yang sesuai dengan permasalahan.

Tahapan 5) Menyajikan portofolio. Paparan portofolio dapat dilakukan dihadapan dosen pengampu matakuliah dan peneliti serta rekan mahasiswa dalam satu 
kelas. Melalui tahapan ini, inference mahasiswa yaitu mmpu membuat kesimpulan dengan tepat dan memilih reason ( $\mathrm{R})$ yang tepat untuk mendukung kesimpulan yang dibuat terlatih dengan baik. Selain itu clarity mahasiswapun juga terasah, yang dimaksud adalah mahasiswa menggunakan penjelasan yang lebih lanjut tentang apa yang dimaksudkan dalam kesimpulan yang dibuat dan mahasiswa mampu memberikan contoh kasus yang mirip dengan permasalahan. Hal ini sesuai dengan indicator critical thingking ketiga dan kelima. Diperkuat dengan pendapat Budimansyah (2009) mahasiswa dengan pengalaman belajar tentang cara mempresentasikan ide-ide dan pemikiran kepada orang lain. Adapun seluruh mahasiswa yang tergabung dalam kelompok menyajikan hasil pekerjaannya dihadapan dosen pengampu, peneliti, dan rekan sekelas.

Tahap ke 6). Merefleksikan pengalaman belajar. Pada tahapan ini indicator critical thingkingnya adalah overview yaitu mahasiswa mampu meneliti atau mengecek kembali secara menyeluruh mulai dari awal sampai akhir, dalam tahap ini mahasiswa diajak untuk melihat kekurangan yang dari tahap pertama sampai dengan tahap keenam, diberikan masukan oleh dosen dan dosen memberikan tanggapan tentang hasil karya atau presentasi seluruh mahasiswa. Tahapan ini layaknya mahasiswa memperoleh kajian ilmu dari dosen tentang keakuratan data, domain atau sumber yang terpercaya dan review hasil diskusi masingmasing kelompok agar mampu meningkatkan kemampuan mahasiswa.

\section{SIMPULAN}

Berdasarkan hasil analisis dan pembahasan penelitian dapat disimpulkan sebagai berikut.

$$
\text { Pelaksanaan }
$$

Model

Pembelajaran Project Citizen mampu Meningkatkan Critical Thinking Mahasiswa Prodi S1 PGSD STKIP Kusuma Negara Semester II Kelas A Tahun Akademik 2018/2019 semester II. Peningkatan tersebut tercermin pada critical thingking mahasiswa. Hal ini dibuktikan pada siklus I Secara umum, hasil analisis critical thingking mahasiswa siklus I dan II pada pertemuan 1 sebanyak 6 dan 19 mahasiswa. Pertemuan 2 sebanyak 9 dan 23 mahasiswa, pertemuan 3 sebanyak 14 dan 27 mahasiswa. Hasil ini menunjukkan bahwa critical thingking mahasiswa mengalami peningkatan di setiap siklus.

Penerapan Model Pembelajaran Project Citizen Meningkatkan Critical Thinking Mahasiswa Mahasiswa Prodi S1 PGSD STKIP Kusuma Negara Semester II Kelas A Tahun Akademik 2018/2019. Adapun langkah atau tahapan Model Pembelajaran Project Citizen yang telah terlaksana adalah (1) Mengidentifikasi masalah, (2) Memilih masalah sebagai bahan kajian kelas, (3) Mengumpulkan informasi, (4) mengembangkan portofolio kelas, (5) Menyajikan portofolio., dan (6) Merefleksikan pengalaman belajar. 


\section{DAFTAR PUSTAKA}

Budimansyah, D. 2009. Inovasi Pembelajaran Project Citizen. Bandung: Program Studi Pendidikan Kewarganegaraan SPs UPI

Cabinet Office Japan Government. 2019. Society 5.0. Diakses dari:https://www8.cao.go.jp/cstp/ english/society5_0/index.html, tanggal 20 Agustus 2019

Chrisnaji Banindra Yudha, 2019. Penerapan Project Based Learning dalam Mata Kuliah Penelitian Tindakan Kelas. DWIJA CENDEKIA: Jurnal Riset Pedagogik 3 (1) (2019) 30-42.

Chrisnaji Banindra Yudha. 2019. pengaruh pendekatan saintifik terhadap kemampuan berpikir kritis mahasiswa. Buana Matematika: Jurnal IImiah Matematika dan Pendidikan Matematika. Volume 9, Nomor 1. P. 31-36

Costa, A. \& Kallick. B. (2014). Dispositions: Reframing teaching and learning. Thousand Oaks, CA: Corwin Pres

Dina Indriani. 2019. Peranan Project Citizen Terhadap Kemampuan Berpikir Kritis Mahasiswa. Jurnal Pancasila dan Kewarganegaraan. Vol 4 No 2 Tahun 2019 p.20-29

Fisher A, Scriven M. 1997. Critical Thinking: Its Definition and Assessment. Point Reyes (CA): Edgepress.

Johnson, E. B. 2002. Contextual Teaching and Learning: Menjadikan Kegiatan Belajar Mengajar Mengasyikkan dan Bermakna. Terjemahan oleh Ibnu Setiawan. Bandung: Mizan Learning Center (MLC)
Kemmis \& Mc. Taggart.1988. The action research planner. Victoria: Deakin University.

Luqman. 2017. Penerapan Model Project Citizen Untuk Meningkatkan Keterampilan Berpikir Kritis dan Kreatif Siswa. Jurnal IImu Pendidikan, Volume 2 Nomor 1, Juni 2017: 44-59.

Nada Santi Ulfah, Solihin Ichas Hamid. 2017. Project Citizen Model In Civic Learning To Improve Students Critical Thinking Skills. Jurnal Antologi UPI Volume 5 Edisi No.1. p. 134145

Parjono,dkk. 2007. Pedoman penelitian tindakan kelas. Yogyakarta: Lembaga Penelitian UNY

Reeve, E. M. (2016). 21st-century skills needed by students in technical and vocational education and training (TVET). Asian International Journal of Social Sciences, 16(4), $65-82$. doi: 10.29139/aijss.20160404

Rohani dan Rube'i, Muhammad Anwar. 2019. Peningkatan Keterampilan Intelektual Melalui Penerapan Model Project Citizen Pada Mata Kuliah Pendidikan Kewarganegaraan. VOX EDUKASI: Jurnal IImiah IImu Pendidikan Volume 10 Nomor 2, p. $93-104$

Suharsimi Arikunto. (2010). Penelitian Tindakan Kelas. Jakarta: Bumi Aksara

Suharsimi Arikunto. (2009). Dasardasar Evaluasi Pendidikan. Jakarta: PT. Bumi Aksara

Suparni. 2016. Upaya Meningkatkan Kemampuan Berpikir Kritis Mahasiswa Menggunakan 
Bahan Ajar Berbasis Integrasi Interkoneksi. Jurnal Derivat Volume 3 No. 2 Desember 2016 (ISSN: 2407 - 3792(Cetak)) P. $40-58$ 